\title{
Analysis on the Beliefs of Chinese Rural Residents
}

\author{
Li Liu
}

Marxism College of Jilin agricultural University Jilin Changchun, 130118, China

Keywords: Belief; religion; rural residents; culture

\begin{abstract}
Belief is a kind of unique religious culture. This paper analyzes the belief of Chinese rural residents, through the methods of literature analysis and investigation, and probes into the cultural phenomenon of the folk beliefs of rural residents with the paradigm of knowledge sociology. The purpose of the study is to reveal the current situation of folk beliefs in the context of China's rural social transformation, and to explore the relationship between folk beliefs and society. Paying attention to the daily knowledge of farmers, to explore the interaction between folk beliefs and society, highlighting the rationality of folk beliefs as a kind of local knowledge, are the important purpose of this paper.
\end{abstract}

\section{Introduction}

Since the reform and opening up, with the relaxation of super political ideology control and transformation of social structure, rural folk beliefs hidden in the rural areas in China resurfaced and became the active elements in folk local knowledge. This is mainly manifested in that a large number of gods' worship, ancestor worship, religious ceremonies, life rituals, spells, spells such as Feng Shui, divination and so on folk beliefs are becoming increasingly popular. Due to different historical conditions and various cultural traditions, the pace of social transformation is of difference, and the degree and performance of each local folk belief are different. Facing with realizing the revival of the beliefs of rural residents, it is quite necessary to study on the issue of beliefs of rural residents in China [1].

\section{Basic Situation of the Current Rural Residents' Belief in China}

Rural residents' belief is worship, taboo idea, behavior, ceremony and activities carried out for the belief of a supernatural power or supernatural that generated spontaneously in the general population in the long process of historical development, and in a certain historical period widely spread in the folk [2].

The revival of the rural residents' belief is reflected in many aspects, such as the increase of the number of believers, the revival and diversification of the belief activities, the construction of the site of beliefs and so on.

(1) The increasing number of believers

Many farmers have this or that kind of folk belief. The number of people who believe in rural folk is increasing, and it has the trend of being young and diverse. The survey results show that people in different gender, age, and cultural level in the countryside are or have become a popular belief among the people. It is no longer the traditional view of taking the old and middle-aged women, illiterate and semi illiterate as the main body. In current national rural residents, about half of the people are believers, so the number of rural residents' believer is very large.

(2) The gradual recovery of activity

Many traditional forms of rural residents' beliefs in China is gradually recovering in practice, including the folk belief activities of individuals, such as divination, burn incense and pray; there are also collective folk belief activities such as worship, temple, mountain and so on. Some believers, in order to meet the needs and comforts of the spirit to hold some folk beliefs activities, such as many villages in the house, the car, the road, etc. 


\section{Investigation on the Belief of Rural Residents in B Village of A City}

Use random sampling method, taking the family as the unit, 360 samples were collected from the B village in A city of our province to carry out a questionnaire survey and 349 valid questionnaires were obtained [3].

\subsection{Analysis of the Basic Characteristics of Samples}

Table 3-1 The basic characteristics of samples $\quad \mathrm{N}=353$

\begin{tabular}{|c|c|c|c|c|c|}
\hline Category & Variables & $\begin{array}{l}\text { Frequency } \\
\text { (N) }\end{array}$ & $\begin{array}{c}\text { Percentage } \\
\quad(\%)\end{array}$ & $\begin{array}{c}\text { Effective } \\
\text { percentage } \\
(\%)\end{array}$ & $\begin{array}{c}\text { Accumulated } \\
\text { percentage } \\
(\%)\end{array}$ \\
\hline \multirow{7}{*}{ Age } & $18-30$ & 102 & 29.2 & 29.6 & 29.6 \\
\hline & $31-40$ & 58 & 16.6 & 16.8 & 46.4 \\
\hline & $41-50$ & 106 & 30.4 & 30.7 & 77.1 \\
\hline & $51-60$ & 43 & 12.3 & 12.5 & 89.6 \\
\hline & Above 61 & 36 & 10.3 & 10.4 & 100.0 \\
\hline & The total & 345 & 98.9 & 100.0 & \\
\hline & $\begin{array}{c}\text { The missing } \\
\text { value }\end{array}$ & 4 & 1.1 & & \\
\hline \multirow{5}{*}{$\begin{array}{l}\text { Marital } \\
\text { status }\end{array}$} & Unmarried & 86 & 24.6 & 24.8 & 24.8 \\
\hline & Married & 218 & 62.5 & 62.8 & 87.6 \\
\hline & $\begin{array}{l}\text { Single after } \\
\text { marriage }\end{array}$ & 43 & 12.3 & 12.4 & 100.0 \\
\hline & The total & 347 & 99.4 & 100.0 & \\
\hline & $\begin{array}{c}\text { The missing } \\
\text { value }\end{array}$ & 2 & 0.6 & & \\
\hline \multirow{3}{*}{ Nation } & Han & 318 & 91.1 & 91.1 & 91.1 \\
\hline & Hui & 31 & 8.9 & 8.9 & 100.0 \\
\hline & The total & 349 & 100.0 & & \\
\hline \multirow{9}{*}{ Profession } & $\begin{array}{l}\text { Agricultural } \\
\text { laborer }\end{array}$ & 108 & 30.9 & 32.3 & 32.3 \\
\hline & Rural manager & 10 & 2.9 & 3.0 & 73.1 \\
\hline & $\begin{array}{l}\text { Self-employed } \\
\text { person }\end{array}$ & 61 & 17.5 & 18.3 & 91.3 \\
\hline & $\begin{array}{l}\text { Migrant } \\
\text { workers }\end{array}$ & 110 & 31.5 & 32.9 & 65.3 \\
\hline & $\begin{array}{c}\text { Private } \\
\text { businessman }\end{array}$ & 9 & 2.6 & 2.7 & 94.0 \\
\hline & Doctors & 7 & 2.0 & 2.1 & 96.1 \\
\hline & Others & 13 & 3.7 & 3.9 & 100.0 \\
\hline & The total & 334 & 95.7 & 100.0 & \\
\hline & $\begin{array}{c}\text { The missing } \\
\text { value }\end{array}$ & 15 & 4.3 & & \\
\hline
\end{tabular}

According to Table 3-1, from the age, 41-50 years old and 18-30 years old occupy the most. From the marital status, the married occupies the majority. In terms of nation, the main object of the investigation is the Han nationality. In the survey of the distribution of the profession, rural workers and migrant workers are the main part, which is in line with the basic pattern of the current distribution of rural occupations [4].

\subsection{Measurement and Analysis of the Current Situation of Rural Residents' Belief}

From three aspects of the cognition, attitude and participation behavior of rural residents to measure, the folk beliefs can be divided into two aspects: belief (concept), ritual (behavior) these two aspects [5]. 


\subsubsection{The Cognition of Rural Residents on Folk Beliefs}

Table 3-2 The cognition of rural residents on folk beliefs

\begin{tabular}{ccccc}
\hline $\begin{array}{c}\text { What do you think } \\
\text { belief is? }\end{array}$ & $\begin{array}{c}\text { Frequency } \\
(\mathrm{N})\end{array}$ & $\begin{array}{c}\text { Percentage } \\
(\%)\end{array}$ & $\begin{array}{c}\text { Effective } \\
\text { percentage } \\
(\%)\end{array}$ & $\begin{array}{c}\text { Accumulate } \\
\mathrm{d} \\
\text { percentage } \\
(\%)\end{array}$ \\
\hline Religious belief & 37 & 10.6 & 10.9 & 10.9 \\
Folk custom & 89 & 25.5 & 26.3 & 37.2 \\
Feudal superstition & 40 & 11.5 & 11.8 & 49.0 \\
Unable to explain & 158 & 45.3 & 46.6 & 95.6 \\
clearly & 15 & 4.3 & 4.4 & 100.0 \\
Others & 339 & 97.1 & 100.0 & \\
The total & 10 & 2.9 & & \\
The missing value & 349 & 100 & & \\
The total &
\end{tabular}

Table 3-2 shows that the people unable to explain clearly the folk belief nature accounted for $45.3 \%$ of all respondents; people think that folk belief is equivalent to the folk custom accounted for $25.55 \%$ of all the respondents; people hold that folk belief is a religion or superstition are respectively $10.9 \%$ and $11.8 \%$. These differences are generally similar to the academic community. In addition, most farmers take folk beliefs as folk customs, and this is basically a consensus in the academic community [6].

\subsubsection{The Cognition of Rural Residents on Folk Beliefs Ceremony}

According to their own situation, the researchers choose the understanding degree and the degree of change of life etiquette, which are divided into "Very...", "Comparatively...", "Basically...", "No..." and so on five levels [7]. In the data processing, they are respectively given 5 points, 4 points, 3 points, 2 points and 1 point in the score.

Table 3-3 The cognition of rural residents on folk beliefs ceremony

\begin{tabular}{lllllll}
\hline Items & $\begin{array}{l}\text { Birth } \\
\text { etiquett } \\
\text { e }\end{array}$ & $\begin{array}{l}\text { One year } \\
\text { old } \\
\text { etiquette }\end{array}$ & $\begin{array}{c}\text { Adult } \\
\text { etiquette }\end{array}$ & $\begin{array}{c}\text { Wedding } \\
\text { etiquette }\end{array}$ & $\begin{array}{c}\text { Birthday } \\
\text { party } \\
\text { etiquette }\end{array}$ & $\begin{array}{c}\text { Funeral } \\
\text { etiquett } \\
\text { e }\end{array}$ \\
\hline $\begin{array}{l}\text { Effective } \\
\text { responding } \\
\text { number }\end{array}$ & 336 & 339 & 321 & 339 & 334 & 334 \\
$\begin{array}{l}\text { The } \\
\text { missing }\end{array}$ & 13 & 10 & 28 & 10 & 15 & 15 \\
$\begin{array}{l}\text { value } \\
\begin{array}{l}\text { The } \\
\text { proportion }\end{array}\end{array}$ & 3.7 & 2.9 & 8.0 & 2.9 & 4.3 & 4.3 \\
$\begin{array}{l}\text { Average } \\
\text { value }\end{array}$ & 4.08 & 3.93 & 2.55 & 4.22 & 3.73 & 4.14 \\
$\begin{array}{l}\text { Standard } \\
\text { deviation }\end{array}$ & 1.1 & 1.008 & 1.545 & 0.936 & 1.165 & 1.141 \\
\begin{tabular}{l} 
Variance \\
\hline
\end{tabular} & 1.211 & 1.016 & 2.386 & 0.875 & 1.357 & 1.302 \\
\hline
\end{tabular}

Table 3-3 shows the birth etiquette, the mean scores of wedding etiquette and funeral etiquette being understood are above 4 points, and the average scores are 4.08 points, 4.22 points and 4.14 points; the mean scores of one-year-old etiquette and birthday party etiquette are 3.93 and 3.73 respectively; while the mean score of the adult etiquette being understood is 2.55 points. 


\section{Concrete Methods to Solve the Problems of the Contemporary Chinese Rural Residents' Belief}

Socialist advanced culture must let the people know, let the people participate in, and let the people share. As mentioned before, the farmers' cultural ability refers to that the farmers as the main cultural body transform the excellent cultural achievements of our country into the internal basic quality and external use of skills of adjusting a harmonious relationship between production and living. It can be said that the majority of rural areas in China has culture, but the farmers do not form the corresponding cultural ability. Rural culture has always been outside the farmers, and the culture outside farmers becomes a direct source of the problem of China farmers' beliefs.

\subsection{Reconstruction of Rural Cultural Cohesion}

Cultural cohesion is the value guiding and integrating ability that takes culture as the basic content, a parasitic place for social beliefs. Reconstruct the spiritual origin of rural culture. The spiritual origin of rural culture is not politics, nor law, but ethics, the "pro-life" ethics. The "pro-life" ethics is expanded as three dimensions, one is the natural respect, heavy land; the second is the family; the third is the situation [8]. Integrate rural cultural tradition and the value orientation of modern culture. To change the current asymmetric relationship of rural spiritual and cultural products between supply and demand, on the one hand, the governments at all levels should continue to strengthen the organization and leadership, include the cultural construction of ideological education and rural peasants in social construction and management schedule, strengthen the education of lower levels of government on farmers' ideology and culture guiding function, and fully protect the funding, personnel, working mechanism and so on; on the other hand, all levels of propaganda and cultural units should tend to change the tendency of work elite and elegance, consciously carry out the creative transformation of socialist core value system, and make abstract ideas into the countryside, and the people.

\subsection{Cultivating Farmers' Cultural Participation Ability}

Cultural participation ability is a realistic representation of the cultural competence of farmers. The cultivation of farmers' cultural participation ability involves three dimensions, namely, the rural community taking county - township (town) as the radius, rural communities, and families taking village as a unit, reflecting as three levels of the rural education, cultural center of villages, and peasant family cultural life. It is necessary to develop rural education. Rural education is a general term for all kinds of education and training activities at the county level or below [9]. The main task of rural education is to transport students to a higher school and cultivate senior personnel for the community; another task is to return to the rural community and reserve and provide advanced productive forces for the vast number of the rural. Additionally, it is necessary to construct village cultural center. It helps to change the monotonous and backward way of life and living environment, optimizes and beautifies the rural living environment; on the other hand, it can eliminate religious superstition, gambling and other abnormal and unhealthy culture from the basis, integrates the excellence in the humanities spirit, artistic content, performance the form of modern civilization and values, legal policy, morality, and other aspects of the criticism and so on into a variety of cultural activities, art activities and communication activities, so as to achieve the effect of guiding and educating in the invisible.

\section{Conclusion}

To solve the problem of farmers' belief in contemporary China is a systematic work. This article believes that the solution to the problem of contemporary Chinese farmers belief, one is to focus on the root causes, the other is to start with the internal roots. Based on the contemporary China rural reality, focus on solving the problem of economic base and the people, so as to truly realize "consolidate the foundation". 


\section{References}

[1] Winterton R, Warburton J. Ageing in the bush: The role of rural places in maintaining identity for long term rural residents and retirement migrants in north-east Victoria, Australia[J]. Journal of Rural Studies, 2012, 28(4): 329-337.

[2] Groth T M, Vogt C A. Rural wind farm development: Social, environmental and economic features important to local residents[J]. Renewable Energy, 2014, 63: 1-8.

[3] Stedman R C, Jacquet J B, Filteau M R, et al. Environmental reviews and case studies: Marcellus shale gas development and new boomtown research: Views of New York and Pennsylvania residents[J]. Environmental Practice, 2012, 14(04): 382-393.

[4] Erickson L D, Call V R A, Brown R B. SOS—satisfied or stuck, why older rural residents stay put: Aging in place or stuck in place in rural Utah[J]. Rural Sociology, 2012, 77(3): 408-434.

[5] Qi S, Yao X, Song L. Current Situation and Reasonable Construction of Consumption Value of Rural Residents in Kongpo[J]. Asian Agricultural Research, 2014, 6(12): 79.

[6] Dasgupta A, Guchhait S K. A comparison of normative values for reverine and non-reverine communities of the Indian Sundarbans: an exploration into socio logical aspect of the residents of Malta river[J]. Int J Human Soc Sci Invent, 2013, 2(12): 42-7.

[7] Yboa B C, Labrague L J. Dengue knowledge and preventive practices among rural residents in samar province, philippines[J]. American Journal of Public Health Research, 2013, 1(2): 47-52.

[8] Chen Y, Shen G, Huang Y, et al. Household air pollution and personal exposure risk of polycyclic aromatic hydrocarbons among rural residents in Shanxi, China[J]. Indoor air, 2016, 26(2): 246-258.

[9] Liang Y, Wang P. Influence of prudential value on the subjective well-being of Chinese urbanrural residents[J]. Social indicators research, 2014, 118(3): 1249-1267. 